Абай атындавы ҚазҰПУ-ц् ХАБАРШЫСЫ «Педагогика вылымдары» сериясы, №3(67), 2020 ж.

17. Kaufman, J., Highfield, K., Guy, J., Leung, S., \& Wallis, K. (2017). Research and evaluation of screen time and digital technology: Report to the Australian Government Department of Education and Training. Melbourne, Australia: Swinburne University of Technology. - 2017. https://docs.education.gov.au/system/files/doc/other/final_report_screen_time_and_digital_technology__20180215.pdf

18. Khalykova G.Z What is your digital literacy?// https://turkystan.kz/article/114893-tsifrly-sauattyly$y$-yz-andaj

\author{
С.3. Нишанбаева ${ }^{1}$ Ж.А. Абилхаирова ${ }^{2}$, А.Мариалхан $^{3}$ \\ ${ }^{1}$ Алматы университеті, Алматы к., Қазақстан \\ ${ }^{2}$ Қорқыт Ата атындавы Қызылорда мемлекеттік университеті, \\ Қызылорда қ., Қазақұстан \\ ${ }^{3}$ Қазақ Ұлттық медициналық университеті \\ Алматы, Қазақстан

\section{СТУДЕНТТЕРДІҢ ОТБАСЫ-АДАМГЕРШІЛІК ҚҰНДЫЛЫҚТАРЫН ҚАЛЫПТАСТЫРУДЫН ӘДІСНАМАЛЫҚ АППАРАТЫ}

Аң̧датпа

Мақалада студенттердің отбасы-адамгершілік құндылықтарын қалыптастырудың әдіснамалық аппаратында әдіснаманың негізгі категориялары, отбасы-адамгершілік құндылықтарды қалыптастырудың әдіснамалық тұғырлары қамтамасыз етілетіндігі қарастырылады. Теориялық талдаулар арқылы ғалымдардың еңбектеріндегі ғылыми әдіснама түсінігінің төрт тобы анықталады. Ғылыми әдіснаманың негізгі категориялары: «тұғыр», «қағида» ұғымдарының қатынасы талданады. Студенттердің отбасы-адамгершілік құндылықтарын қалыптастырудың әдіснамалық тұғырлары: аксиологиялық, әлеуметтік-гуманистік, жүйелілік-құрылымдық, іс-әрекеттік, мәдениеттанымдық тұвырлар басшылыққа алынады. Әрбір әдіснамалық тұғырдың функционалдық қызметін талдай отырып, отбасы-адамгершілік құндылықтарын қалыптастырудың атрибуттары сараланады. Студенттердің отбасы-адамгершілік құндылықтарын қалыптастырудың әдіснамалық аппаратының тұжырымдарының негізін диагностикалауда анықтау экспериментінің жұмыстары жүргізілді. Студенттермен эксперименттік алаңда М.Рокичтің «Құндылық бағдарды анықтау» әдістемесі жүргізіліп, зерттеу нәтижесінің пайыздық, сандық көрсеткіштері талданып өңделеді.

Түйін сөздер: отбасы-адамгершілік құндылықтар, әдіснамалық тұғырлар, аксиология, гуманизм, жүйелілік, іс-әрекеттік, мәдениеттанымдық.

\author{
С.3. Нишанбаева ${ }^{1}$ Ж.А. Абилхаирова ${ }^{2}$, А.Маршалхан $^{3}$ \\ ${ }^{1}$ Университет Алматы \\ ${ }^{2}$ Кызылординский государственный университет имени Коркыт Ата \\ ${ }^{3}$ Казахский Наџиональный медицинский университет

\section{МЕТОДОЛОГИЧЕСКИЙ АППАРАТ ФОРМИРОВАНИЯ} \\ СЕМЕЙНО-НРАВСТВЕННЫХ ЦЕННОСТЕЙ СТУДЕНТОВ
}

Аннотация

В статье говорится о методологическом аппарате формирования семейно-нравственных ценностей студентов, обеспечиваются основные категории методологии, методологические подходы к формированию семейно-нравственных ценностей. Теоретическим анализом определяются четыре группы представлений научной методологии в трудах ученых. Анализируются основные категории научной методологии: соотношение понятий «подход», «принцип». Методологические подходы к 
формированию семейно-нравственных ценностей студентов: аксиологические, социально-гуманистические, системно-структурные, деятельностные, культурологические подходы. Анализируя функциональную деятельность каждого методологического подхода, будут проанализированы атрибуты формирования семейно-нравственных ценностей. Проведена работа по диагностике основ методологического аппарата формирования семейно-нравственных ценностей студентов. На экспериментальной площадке студентов была проведена методика М.Рокича «Определение ценностного ориентирования», проанализированы процентные, количественные показатели результатов исследования.

Ключевые слова: семейно-нравственные ценности, методологические подходы, аксиология, гуманизм, системность, деятельностность, культуропознавательность.

\author{
S.Z. Nishanbaeva ${ }^{1}$, Zh.A.Abilkhairova ${ }^{2}$, A.Marshalhan ${ }^{3}$ \\ ${ }^{1}$ University Almaty \\ ${ }^{2}$ Korkyt Ata Kyzylorda State University \\ ${ }^{3}$ Kazakh National Medical University
}

\title{
METHODOLOGICAL APPARATUS FOR FORMING STUDENTS' FAMILY AND MORAL VALUES
}

\begin{abstract}
The article describes that the methodological apparatus for the formation of family and moral values of students provides the main categories of methodology, methodological approaches to the formation of family and moral values. Theoretical analysis defines four groups of representations of scientific methodology in the works of scientists. The main categories of scientific methodology are analyzed: correlation of the concepts «approach» and «principle». Methodological approaches to the formation of students' family and moral values: axiological, socio-humanistic, system-structural, activity-based, cultural approaches. Analyzing the functional activity of each methodological approach, the attributes of the formation of family and moral values will be analyzed. The work was carried out to diagnose the basics of the methodological apparatus for the formation of family and moral values of students. On the experimental site of students, the method $\mathrm{m}$ was carried out. Rokicha «Definition of value orientation», analyzed the percentage and quantitative indicators of research results.
\end{abstract}

Keywords: family and moral values, methodological approaches, axiology, humanism, consistency, activity, cultural awareness.

Кіріспе. ЖОО-да білім алушылардың кәсіби білім, білік, дағдыны ғана емес, практикалық ісәрекетте өзінің әлеуетін табысты жүзеге асыруға мүмкіндік беретін құндылықтар жиынтығын меңгеру қоғам сұранысынан туындап отырған мәселелердің бірі. Бүгінде құндылықтарды меңгеру отбасынан бастау алады, сондықтан отбасы мәселесін зерттеп, оның мәнін ашып көрсетуде әдіснамалық тұғырларды сәйкестендірудің қажеттілігі туындауда. Педагогикалық жоғары оқу орындары студенттерінің отбасы-адамгершілік құндылықтарын қалыптастыруда түзілетін әдіснамалық тұғырлар қойылған зерттеу міндеттерін шешудің негізгі жолы болады, ол осы шешімдердің бағыттары мен стратегиясын айқындайды. Сонымен бірге тұғыр (тәсіл, тұрғы) педагогикалық ісәрекеттің өзара байланысты идеялары мен ұғымдарының сапалық жиынтығын пайдалануда әдіснамалық бағдар ретінде мазмұндалады.

Осы орайда «Қазақстан 2020: болашаққа жол» атты Қазақстан Республикасы мемлекеттік жастар саясатының 2020 жылға дейінгі тұжырымдамасында: «Қазақстанда отбасы әрқашан әлеуметтің аса маңызды құраушы элементі ретінде қарастырылып келеді. Ол қоғам болмысының, мемлекеттің негізі, адалдық, адамгершілік және рухани үйлесім жүйесіндегі маңызды буын болып табылады»; «...Өзі және өз жақындары үшін әлеуметтік жауапкершілік сезімін қалыптастыру отбасындағы тәрбиеден бастау ала отырып, жастар саясаты мәселелерінде негіз болуы қажет. Өмірдің құндылығы, қауіпсіздігі және оны жалғастыру отбасымен тікелей байланысты» - делінген. Мұндай тұжырымдамалық идеялар жастар саясатына, оның ішінде статистикалық көрсеткішімен басым келетін студент жастарға әлеуметтік міндет ретінде ұсынылып отырғанының өзі отбасындағы жеке тұлғаның қоғаммен өзара әрекеттестігінің негізгі құралы екендігінің кепілі болады [1]. 
Президентіміз Қ.К. Тоқаевтың «Жаңа жағдайдағы Қазақстан: іс-қимыл кезеңі» атты 2020 жылдың 1-қыркүйегіндегі Жолдауында: «Ұлттың жаңа болмысы» бөліміндегі «...Қазіргі міндет халқымыздың жаңа болмысын қалыптастыру, тұтас ұлт сапасын арттыру. ...Мен халқымыздың әлем үлгі тұтарлық жақсы қасиеттерінің көбірек болғанын қалаймын. Ұлтымыз жаңа сапаға көшуі үшін біздің күнделікті өмірлік ұстанымдарымыз да өзгеруі керек» деп көрсетеді (https://primerminister.kz) [2]. Президентіміздің Жолдауында көрсетіп отырғанындай, жоғары білім берудің жаңа парадигмасы нәтижесі білім алушылардың құндылықтар жүйесін қайта қарауға әкелетін білімге бағытталып отыр. Өйткені білімнің өзінің құндылықтар жүйесі - субъектілердің өзін-өзі өзгертіп, өзін-өзі дамытуында мақсаттарға жетіп, нарықтың бәсекелестік заңдарына шыдай отырып, табысты өмір сүруге дайындау болып табылады.

Барлық нормативтік құжаттарда көрсетіп отырғанындай отбасы - бұл табысты өмір сүрудің баспалдағы. Отбасы құндылығы әлеуметтік өмірдің ірі ауқымдағы құрылымы. Сондай-ақ, ол материалдық және рухани тұрғыдағы қатынастарға негізделеді. Бұл ретте ЖОО-да оқу-тәрбие үдерісінің маңызды бағыты студенттердің отбасы-адамгершілік құндылықтарын қалыптастыру мәселесі болады.

Мақаламызда педагогикалық жоғары оку орындары студенттерінің отбасы-адамгершілік құндылықтарын қалыптастырудың әдіснамалық бағдарларын тереңірек зерделеу негізінде әдіснама ұғымының мәніне, оның категорияларына талдау жасауды жөн санаймыз.

Зерттеудің әдіснамасы. Біз, еңбегімізде әдіснамалық категорияларды, отбасы-адамгершілік құндылықтарды қалыптастырудың әдіснамалық тұғырларын, функционалдық жағдайда, одан бұрын теориялық, яғни ассоцациялау, классификациялау, топтау сынды әдістерді логикалық тұрғыдан «әдіснамалық аппарат» жиынтығында ұсынбақшымыз.

Ендеше біз, жалпы педагогикадағы әдіснама ұғымы, оның негізгі категорияларына философиялық, педагогикалық-психологиялық ғылым саласы бойынша талдап өтейік.

Педагогикалық-психологиялық білімдер жүйесінде ғылыми таным мен ғылыми таным құралының теориялық мәселелерін шешу жолдарына «әдіснама» ұғымы қызмет етеді. Ал философиялық энциклопедиялық сөздікте «әдіснама» - (грек сөзінен «methods» - зерттеу жолы, таным, ілім, білім; «logos» - сөз, түсінік) ғылыми таным әдістері туралы оқу; қандай да бір ғылымда қолданатын әдістердің жиынтығы және амалдар жүйесі мен тәжірибелік теориялық іс-әрекетті ұйымдастыру, құру тәсілдері деп талданады [3].

Біздің зерттеуімізше, біршама психологиялық-педагогикалық сөздіктерде әдіснама, теориялық және практикалық іс-әрекетті ұйымдастырудың және құру қағидаларының, тәсілдерінің жүйесі ретінде көрініс табады. Мұнда әдіснаманың негізіне белгілі бір білімдер (ұғымдар, заңдылықтар және т.б.) кіреді.

Ғылыми зерттеулерде әдіснама ұғымының сипаты туралы түрлі тұжырымдаулар кездеседі. Біз, зерттеулерге сүйене отырып, келесідей топтастырып көрсетуге болады. Ендеше 1-суретте әдіснама ұғымының 4 топқа топтастырылуын ұсынамыз.

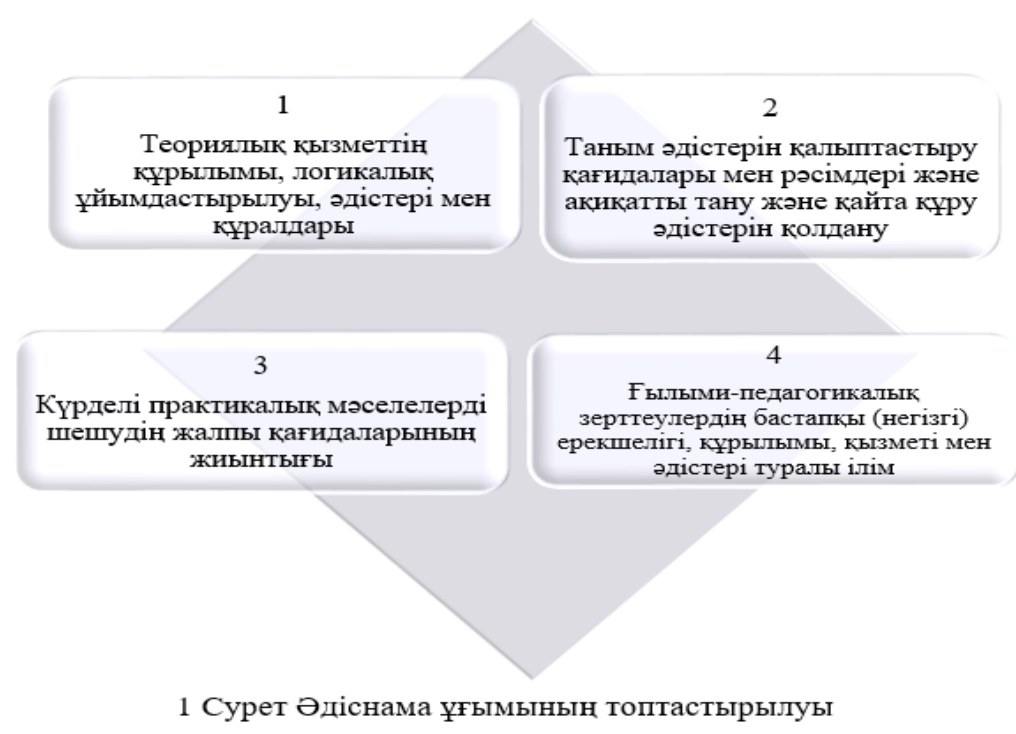


Бірінші mon - теориялық қызметтің құрылымы, логикалық ұйымдастырылуы, әдістері мен құралдары туралы;

Eкінші mon - таным әдістерін қалыптастыру қағидалары мен рәсімдері және ақиқатты тану және қайта құру әдістерін қолдану туралы;

Yшінші mon - күрделі практикалық мәселелерді шешудің жалпы қағидаларының жиынтығы туралы;

Tөртінші mon - ғылыми-педагогикалық зерттеулердің бастапқы (негізгі) ерекшелігі, құрылымы, қызметі мен әдістері туралы ілім деп санайды [4].

П.И. Пидкасистыйдың зерттеулеріне сүйенсек, педагогика әдіснамасының пәні білім беру аясында болатын қарым-қатынас жүйесінде болатын үдерістердің заңдылықтары деп талданады. Ғалым білім берудің мақсаты мен мазмұнының шартталған өзара әрекеттесу тәсілдері және оны шарттайтын әдістер мен формасын ұсынады. Мұнда субъектілердің қарым-қатынасы, іс-әрекетін басқару мен ұйымдастыру механизмдері іске асып, ол субъектілердің ұжым және топта өзін-өзі ұйымдастыруы, рефлексиясы, өзін-өзі тәрбиелеуін қамтамасыз етеді [5].

Әдіснамалық тұғыр ғылымтану, ғылым және білім философиясы, ғылым және білім әдіснамасы құрылымында, ғылым мен білімнің жаңа парадигмасын саналы түсіну, ғылым және білімнің даму үдерісі негіздеріне сүйенеді [6].

Бізге белгілі болғандай, студенттердің отбасы-адамгершілік құндылықтарын қалыптастырудағы әдіснамалық аппаратын құруда келесідей тұғырларды: жүйелілік-құрылымдық тұzыр, аксиологиялық тұвыр, іс-әрекеттік тұвыр, әлеуметтік-гуманистік тұzыр, мәдениеттанымдық тұzырларды басшылыққа алдық. Ендеше, зерттеу облысымыз бойынша негізге алынған әдіснамалық тұғырларды талдауды келесідей нақтылап өтейік.

Тұлғаның рухани-адамгершілік құндылықтарының қалыптасуы өркениеттер жетістіктерін, қандай да бір даму тетіктерін және барлық бағдарларын айқындайтын білімдердің нақтылы-тарихи жүйесі ретінде көрініс табуы аксиология түсінігін алға шығарады. Аксиологиялық тұғыр - бұл отбасының микро, мезо және макрофакторлармен өзара әрекеттестігінің аксиологиялық әлеуетін ашып көрсетеді. Бұл ретте студенттердің отбасы-адамгершілік құндылықтарын қалыптастырудағы үдеріс ретінде сипатталатын әлемге, адамға, өз-өзіне қатысымды жалпы адамзаттық құндылық үлкен рөл атқарады. Сондай-ақ, әлеуметпен, мәдениетпен болып жатқан қарым-қатынасындағы отбасы-адамгершілік мәндерді ұғынуда білім алушы өз білімінің, өмірінің мәніне ие болуы да аксиологияны қамтамасыз ете алады. Білім беру үдерісінде жеке адамды тәрбиелеу жолында академиялық пәндер, отбасы педагогикасы, отбасы психологиясы, отбасы тәрбиесіндегі академиялық адалдықты және т.б. қолдау мен дамуы іске асырылады, сонымен қатар, тұлғаның негізгі құндылықтары - кәсібилік, өзіне сенімділік, жауапкершілік т.б. сапалары негізге алынады [7].

Ғалым О.И. Воложина зерттеулерінде аксиологиялық тұжырымдама отбасының құндылық статусының трансформациясы мәселесін талдауда және оған мақсатты бағытта ықпал ету мүмкіндіктерінде деп талданады. Аксиологияның құрылымдық тұжырымдамасында индивидтің отбасылық қатынастар моделін айқындайтын, адамдардың іс-әрекеті мен бірлескен өмірі нәтижесінде қалыптасқан мәдениет элементтерінің белгілі жиынтығы ретінде түсіндіріліп, ал сол элементтер отбасы, оның әлеуметтік-мәдени мәні туралы қалыптасқан түсініктерді қолдайтын, қоғамдық құрылымның алмасу үрдісінде әлеуметтік-мәдени сәйкестілік механизмдерін сипаттап береді [8].

Білім алушылардың отбасы-адамгершілік құндылықтарды қалыптастырудағы әлеуметтік-гуманистік тұғыр негізгілердің бірі болады.

Әлеуметтік-гуманистік тұғырда білімнің тұлғаға бағытталуы, білім мазмұнының ашық салтанатта жариялануы, сонымен бірге заман талабына сай білім қорымен қаматамасыз ету және ұлттық білім беру жүйесінің гуманистік оқыту болатындығы белгілі.

Бұл тұғырдың негізгі бағдарын сипаттауда біз, гуманитарлық парадигма, гуманистік тәрбие деп аталатын ғылыми түсініктерге сипаттаулар беріп өтуді жөн санаймыз. Қазірде гуманитарлық парадигма түсінігі ғылыми зерттеулерге «адами өлшем» деген категорияны алып келді. Мұндағы ғылыми жаратылыстану ғылымының парадигмасы ғылымның нәтиже беруі экспериментке бағытталса, ал танымның гуманитарлық түрі даралыққа, адамның жеке тұлғалық қасиеттеріне сүйеніп, адами құндылық әлеміне бағытталған «субъективтік» бағытты негіздеп көрсетеді. Ал бұл ретте гуманистік түсінік сипаттамасын: адамның сананы құнды-мағыналы игеруі, оның салыстырмалы, өзгерісті болатынын түсінуі қамтамасыз ете алады. Бұл айтылғандардың барлығы дерлік гума- 
нитарлық парадигманы құрылымдауға септігін тигізері белгілі [9].

Әлеуметтік-гуманитарлық тұғырдың бағдарын сипаттатын келесі бір ғылыми түсінік гуманистік тәрбие болады, ол рухани құндылықтардың әдіснамалық негізі іспеттес. Жоғары мектеп педагогикасы бүгінгі күні көптеген жалпы ғылымилық, әлеуметтік-философиялық; әлеуметтік-мәдени және адамгершілік-эстетикалық үдерістердің бірігуіне алып келеді. Қоғам талаптарындағы отбасыадамгершілік мәселесі оның талаптарына сәйкес тәрбиенің құндылық сипаттарын қайта анықтаудағы өзекті мәселе ретінде қарастырылады. Оның алғышарты тұлғада қайырымдылықты, шыншылдықты, әділдікті, еркіндікті қалыптастыру, әлеуметтік-гуманистік құндылықтарды дамыту болады. Тәрбие практикасында бүгінгі күні жалпыадамзаттық негізгі құндылықтарды анықтау, бекіту қажеттілігі бар. Білім алушылардың отбасы-адамгершілік құндылықтарын қалыптастыруда - әрқайсының отбасы мүшесі ретінде гуманистік көзқарасы мен сенімдері болуы шартты жағдай [10].

Бізге, жалпыадамзаттық құндылықтарды, яғни адам, отбасы, еңбек, білім, мәдениет, отан, жер, әлем т.б құндылықтарды зерделеу педагогика бойынша әлеуметтік-гуманистік тұғыр отбасын адамзатпен байланысты әлеуметтік-мәнді құбылыс ретінде және бірмезгілде отбасыға субъектілік (тұлғалық) құндылық ретінде дамитын социум деп қарастыруға мүмкіндік береді. Сондықтан атаулы тұғырды тұрақты, қайталанатын белгілер жиынтығын игерген әлеуметтік феномен ретінде отбасының өзіндік ерекшеліктерін анықтауға бағдарланған деп айтуға болады. Отбасының топтық өзегі «ана-бала», «әке-бала», «ана-әке» қатынасынан тұратын некелік одақ, әлеуметтік институт және жауапкершілік, парыз және басқа әлеуметтік нормаларды институциализацияландыру формасы. «Жаңа өмір» нәтижесі - отбасынан басталатынын негізге аламыз [11].

Біртұтас бүтіндікті құрайтын өзара байланысты бөлшектердің ретке келтірілген жиынтығы мен олардың арасындағы қатынасы жүйелілік-құрылымдық тұвыр болады. Жүйелілік-құрылымдық тұғыр жалпы ғылыми-әдіснамалық зерттеудің бір құралы ретінде қарастырылады. Себебі оқу-тәрбие процесін және бір-бірімен байланысты құбылыстарды жүйелі зерттеуге қажет сапалы ғылыми тұғыр ретінде танылған.

Жүйелілік-құрылымдық тұғыр педагогикалық зерттеулер үшін В.В. Краевский, Г.П. Щедровицкийлердің, пихологиялық зерттеулерде А.А. Бодалев, В.А. Ганзин, Е.А. Климов, А.Н. Леонтьев, Б.Ф. Ломов, К.К. Платоновтардың тұжырымдамаларында нақтылаулармен қарастырылады.

Жүйелілік тұрғыдан қоғамның экономикалық жағдайлары мен отбасы орындайтын функциялар сипаты, олардың иерархиясы арасындағы байланыстарды ғалым М.С.Мацковский нақтылап көрсете білген. Сонымен қатар қоғам мен отбасының индивидке қарым-қатынасын белгілейтін тұлғаның қажеттіліктері арасындағы диалектикалық байланысты зерттейді [12].

Осы орайда педагогикалық құбылыстар мен өзара байланысын бағдарлап, отбасылық қатынастар типін ашып көрсетеді. Зерттеулерге сүйенсек, тұғырдың жиынтық ретінде қарастыратыны: білім беру мақсаты, студенттерге отбасы-адамгершілік құндылықтарын қалыптастырудағы педагогикалық үрдіс субъектілері (оқытушы, болашақ мамандар) болмақ. Білім алушылардың отбасы-адамгершілік құндылықтарын қалыптастыру жағдайында білім беру мазмұны білім, білік, дағды, отбасы-адамгершілік құндылықтар, өмірлік іс-әрекет тәжірибесі, психологиялық ұлттық мінез, отбасылық тәжірибе жүйесінен құралады. Онда студенттердің отбасы-адамгершілік құндылықтарын қалыптастыру үрдісін ұйымдастырудың әдістері мен түрлері, мәліметтер қоры басты назарға алынуы тиіс.

Білім алушылардың отбасы-адамгершілік құндылықтарын қалыптастырудағы теориялық және практикалық зерттеулердің жүйелілік сипаттамалары жайлы білімнің қажеттігін көздейді.

Ал бұл тұстағы жүйелілік-құрылымдық тұғыр отбасын, отбасындағы құндылықтарды, отбасыадамгершілік құндылықтарын қалыптастырудағы жекелеген үрдістер мен сапаларды басқа жүйелермен байланысады. Олардың әсерінен отбасы-адамгершілік құндылықтарының прогрессивті дамуын қамтамасыз етеді. Сондай-ақ, отбасы-адамгершілік құндылықтарды қалыптастыруды жүйе ретінде зерттеуге мүмкіндік аламыз.

Келесі бір тұғыр ол, іс-әрекеттік тұzыр тарихи, психологиялық, педагогикалық зерттеулерде нақты ғылыми-әдіснамалық ұстаным болып саналады. Бүгінде отбасында еңбек педагогикасының аясы тарылды деуге болады. Бірақ педагогикалық үдерісті қайта құру немесе өзгерістер енгізудің алғашқы формасы еңбек екені анық. Өмір сүру тәртібінде адамның материалдық және рухани байлықтарды жасаудағы іс-әрекеттері еңбек барысында атқарылып, айналасын қоршаған дүниені шығармашылықпен өзгеріске түсіріп отырады. Студенттерді өмірге және жан-жақты іс-әрекеттерге дайындауда олардың мүмкіндіктерін ескеріп, өмір тіршіліктеріне қажетті істерге тартып, олардың өмірін әлеуметтік және адамгершілік тұрғыдан ұйымдастыру қажеттігі туындайды [13]. 
Тұлға өзінің қажеттіліктерін қанағаттандыруда объектіге мақсатты бағытталған ықпал жасайды да, отбасының қоғаммен өзара белсенді әрекеттеседі, бұл ретте адам субъекті рөлін атқарады. Мұндағы қойылған зерттеу міндеттерін шешудің негізгі жолы тұғыр болғандықтан, ол осы шешімдердің бағыттары мен стратегиясын айқындайды. Әдіснамалық бағдар тұғыр (тәсіл, тұрғы) ретінде педагогикалық іс-әрекеттің өзара байланысты идеялары мен ұғымдарының сапалық жиынтығын пайдалануда рөлі көрінеді.

Зерттеулер көрсетіп отырғанындай, ғалым Е.Н. Степановтың еңбектерінде тұлғалық-бағдарлық тұғырды педагогикалық қызметтегі әдістемелік бағдар ретінде анықтап, өзара байланысты түсініктер, идеялар және әрекет ету тәсілдері жүйесіне тірек болу арқылы тұлғаның өзін-өзі тану, өзін-өзі көрсету және өзін-өзі жүзеге асыру, өзінің қайталанбас даралығын дамыту үдерістерін қамтамасыз етуі және қолдауы мүмкін деп көрсетіледі. Ғалымның тұжырымдауынша, тұлғалық-бағдарлық тұғырда студенттермен әрекеттесетін мемлекеттік және қоғамдық институттардың емес, көп жағдайда олардың қызығушылықтары мен қажеттіліктерін қанағаттандыруға апарары анық [14].

Бізге белгілі болғандай, профессорлық-оқытушылар құрамы студенттерде әдеттегі әлеуметтік қасиеттерді қалыптастыруға емес, олардың әрқайсысында әмбебап тұлғалық қасиеттерді дамытуға негізгі күш салады, бұл оқытушылар мен студенттер арасында субъекті-субъектілік қатынастардың пайда болуына әсер ету қажет деп санаймыз.

Мысалы, Г.Гегель теориялары бойынша іс-әрекеттік тұғырдың заттық әрекет категориясының негізінде психиканы зерттеу қағидасы болады да [15]; ал А.Н. Леонтьевтың теориясына сәйкес индивидтің әрекетіндегі психологиялық бейненің құрылымы және қызметін мазмұндайды деп тұжырым береді [13, б. 304].

Білім алушылардың отбасы-адамгершілік құндылықтарын қалыптастырудың әдіснамалық негіздерін реттеуде мәдениеттанымдық тұzырдың маңызы ерекше екендігін атап айтамыз.

Ғылыми еңбектердегі талдауларда мәдениеттанымдық тұвыр - тұлға қалыптастырудағы таным мен педагогикалық іс-әрекеттерді қайта құруға немесе өзгерістер енгізуге бағыт-бағдар беруде мәдени құндылық іліміне сүйенеді. Аталмыш тұғыр арқылы студенттердің отбасы-адамгершілік құндылықтарын құрылымдауда мәдениетпен объективтік байланысы арқылы студенттің мінезқұлқындағы құндылықтар жүйесін зерттейді. Өйткені адам мәдениет арқылы дамығандықтан сол мәдениетке жаңа элементтер енгізуге үлес қосады. Сонда бұл тұстағы жаңа элемент мәдениетпен байланыстағы болашақ отбасын құруға құндылықты негіздегі даярлығы және отбасы-адамгершілік құндылықтарын игеруі болып табылады. Сол себептен, адам мәдениет құндылықтарының жүйесін игеріп өзін-өзі дамытса, екінші жағынан, отбасында құндылықтарды қалыптастыру мәдениет субъектісі болуға жағдай туғызады [16].

В.В. Сериков оқу үдерісі субъектілерінің тұлғалық қызметін толық көрсету және дамыту үшін жағдайлар жасау қажеттілігін ерекше атап көрсетеді: мотивация (әрекетті қабылдау және негіздеу), байланыстыру (сыртқы әсерлер мен ішкі сананың түрткілеріне қатысты), коллизиялық (өмірдің жасырын қайшылықтарын көру), сыни (сырттан ұсынылатын құндылықтар мен қағидаларға қатысты), рефлексивтік, мағыналы-шығармашылық, бағдарлы (дүниенің жеке бейнесін - жеке дүниетанымды құру), ішкі дүниенің өзін-өзі реттеуін және орнықтылығын қамтамасыз ететін қызметтер, шығармашылықпен, жасампаздықпен, өзінің міндеттерін жүзеге асыру (өзін айналасындығыларға мойындатуға талпыну), өзі талабына қарай рухани деңгейін қамтамасыз ету [17].

Ғалымдар отбасылық рухани-адамгершілік құндылықтарға қатысты көптеген теориялар мен көзқарастарды бөліп көрсетеді. Ең бастысы гуманистік рухани-адамгершілік жалпыадамзаттық құндылықтар болып табылады, олар: сүйіспеншілік, жақсылық, ата-ана болу, жауапкершілік, рухани бірлік, қайырымдылық, парыз; бұлардың барлығы адамның тұлғаның ішкі қасиеттеріне, адамның игілігі мен жер бетіндегі өмірге бағдарланған, отбасылық рухани-адамгершілік құндылықтарды қалыптастырудың құрушылары болып табылады.

Р.Хили бойынша отбасының құрылымдық сипаты бес тәсіл тұрғысынан ашып көрсетіледі: институционалды-тарихи көзқарас (эволюционизм); құрылымдық-функционалдық; интеракционалистік - рөлдік талдау (символикалық интеракционизм); ситуациялық-психологиялық көзқарас; дивелопменталдық көзқарас (отбасының өмірлік циклінің дамуына негізделген) [18].

Отбасылық құндылықтар кешенді феномен ретінде әртүрлі ғылым тұрғысынан қарастырылады. Философияда құндылықты түсінудің екі тұғыры қалыптасқан: объективтік-абсолюттік (И.Кант, В.Виндельбанд, Г.Риккерт); субъективтік - релятивтік (Р.Б. Перри, Дж.Дьюи).

Бүгінгі таңда қалыптасқан тәжірибеге сүйене отырып, отбасының құрылымын, мазмұнын сипаттайтын тұжырымдамалар да баршылық екендігі айқындалды. 
Осы орайда, зерттеуімізде отбасының мәні мен құрылымы жөніндегі әртүрлі тұжырымдамаларға сүйене отырып, отбасы-адамгершілік құндылықтарды қалыптастырудың әдіснамалық негіздерін анықтаудың тұғырлары айқындалды (1-кесте).

Кесте 1 - Педагогикалық жоғары оқу орындары студенттерінің отбасыадамгершілік құндылықтарын қалыптастырудағы тұғырлар

\begin{tabular}{|c|c|c|}
\hline № & Тұғырлар & Функциялары \\
\hline 1 & 2 & 3 \\
\hline 1 & $\begin{array}{l}\text { Аксиологиялық } \\
\text { тұғыр }\end{array}$ & $\begin{array}{l}\text { Отбасының микро, мезо және макрофакторлармен өзара } \\
\text { әрекеттестігінің аксиологиялық әлеуетін ашып көрсетеді. }\end{array}$ \\
\hline 2 & $\begin{array}{l}\text { Әлеуметтік- } \\
\text { гуманистік тұғыр }\end{array}$ & $\begin{array}{l}\text { Отбасының әлеуметтік мәнін және оның басқа әлеуметтік } \\
\text { институттармен өзара әрекеттестігін қарастырады. }\end{array}$ \\
\hline 3 & $\begin{array}{l}\text { Жүйелілік- } \\
\text { құрылымдық тұғыр }\end{array}$ & Отбасылық қатынастар типін ашып көрсетеді. \\
\hline 4 & Ic-әрекеттік тұғыр & $\begin{array}{l}\text { Отбасынын қоғаммен өзара белсенді әрекеттесуі, онда адам } \\
\text { субъекті рөлін атқарып, объектіге мақсатты бағытталған } \\
\text { ықпал жасайды және өзінің қ қажеттіліктерін } \\
\text { қанағаттандырады. }\end{array}$ \\
\hline 5 & $\begin{array}{l}\text { Мәдениеттаным } \\
\text { дық тұғыр }\end{array}$ & $\begin{array}{l}\text { Студенттердің } \quad \text { отбасы-адамгершілік } \\
\text { құрылымдауда мәдениетпен объективтік байланысы негізінде } \\
\text { студенттің мінез-кұлқындағы құндылықтар жүйесін зерттейді. }\end{array}$ \\
\hline
\end{tabular}

Кестеде көрсетілген тұғырлар педагогикалық жоғары оқу орындары студенттерінің отбасы-адамгершілік құндылықтарын қалыптастыруда маңызды рөл атқарады. Бұлардың ішіндегі ең маңыздысының бірі құндылық тұғыры, оның мәні отбасын құндылық ретінде қарастырумен сипатталады.

Құндылықтың белгілі бір тарихи-мәдени жағынан шоғырланған және жалпыадамзат пен жеке этнос мәдениетінің мәнін көрсететін адамның өзінің мінез-құлық нормалары мен мақсаты туралы жалпы түсінігі екенін ескеретін болсақ, әлеуметтік қоғамдық қатынастар институты формасындағы заттандырылған элемент ретінде отбасында қалыптасады. Демек, құндылықтардың пайда болуы, біріншіден, адам мен қоғамның қажеттіліктерін қанағаттандыратын заттар, құбылыстар мен олардың сапаларымен байланысты болса, екінші жағынан, құндылық адам мен қоғамның заттарды, құбылыстарлы бағалауымен байланысты пайымдаулары ретінде қатысады [19].

Т.Парсонстың құрылымдық-функционалдық тұжырымдамасына сәйкес құндылықтар кез келген әлеуметтік жүйе және оның құрамдас бөліктерінде өзінің бірлігі мен тұтастығын сақтау, өзін-өзі реттеу, ортақ келісімге келуді жүзеге асыру үшін қалыптастырылған ең жоғарғы ұстанымдар [20].

Отбасын талдауда құрылымдық-функционалдық теория тұрғысанн ұсынған талаптар маңызды. Олар отбасы қызметтерінің әмбебаптығын қолдайды, бірақ әртүрлі мәдениеттегі өзіндік ерекшелігін теріске шығармайды. Бұл теория отбасы мәртебесі мен рөлінің біріншілік идеясын басшылыққа алады.

Н.Л. Москвичеваның психологиялық зерттеуінде студент тұлғасының құндылық бағдар жүйесінің оның тұлғалық ерекшеліктері мен әлеуметтену факторларының байланысында отбасына құндылық бағдары зерттелінеді [21].

C.Е. Нұрмұратов құндылықтар типтерінің жіктемесін бөліп көрсетуде мынадай тұжырымдамаларға сүйенеді: натуралистік психологизм, аксиологиялық трансцендентализм, персоналистік онтологизм, мәдени-тарихи релятивизм, әлеуметтанушылық [22].

Н.С. Әлқожаева өзінің «Қазіргі кездегі білім беру парадигмалары контексінде тұлғаның рухани дүниесін қалыптастырудың ғылыми-педагогикалық негіздері» атты монографиясында жастардың мінез-құлық тәртібінің де сапасын, рухани-адамгершілік тәрбиесіне әсер ететін факторлар ретінде қоршаған ортасы, табиғат, дене еңбектерінің түрлері, экономикалық жағдайлар мен ұлттық салтдәстүрлер, әдет-ғұрыптарды зерделейді. Ғалымның пікірінше: «...жастардың мінез-құлқының, тәртібінің және қарым-қатынасы мен іс-әрекетінің өзгеруіне, адамгершілік жағынан қатаюына мүмкіндік жасайды. Басқаша айтқанда, оның қалыптасуына саяси, экономикалық, руханилық, адамгершіліктік факторлар мен биологиялық, физиологиялық факторлар да әсер етеді, ал оның мәні, нәтижесі рухани- адамгершілік құндылық сипатынан көрінеді. Негізінен рухани құндылықтар білім беру процесінде қалыптастырылады. Мұндағы білім беру - жалпы адамзаттық құндылық болып табылады. Алайда, білім беру жалпыадамзаттық құндылықтармен қатар индивидуалды- тұлғалық 
деңгейде әртүрлі дәрежеде танылады» делінген. Н.С. Әлғожаеваның пікірінен бізге белгілі болғандай, әрбір отбасының қалыптасқан әдет-ғұрпы, салт-дәстүрі болады. Сонымен бірге жалпы қазақ отбасына тән ортақ дәстүрлерді негізге алған [23].

А.В. Мудрик педагогикалық талдау тұрғысынан, отбасы адамды әлеуметтендірудің маңызды факторы болып табылады деп есептей отырып, олардың әлеуметтенуінің жеке кезеңдерінде ажыратылатын және өмір жолында болатын отбасының маңызды әлеуметтендіру функцияларын анықтайды: адамды физикалық және эмоционалдық қамтамасыздандыру; адамның психологиялық өрісін қалыптастыру және жыныстық рөлін әлеуметтендіру; баланың ақыл-ойын дамыту; тұлғаралық және этникааралық қатынастар саласында негізгі құндылық бағдарын қалыптастыру; адамның отбасылық рөлдерді орындау нормалары мен стилдерін меңгерту; адамға әлеуметтік-педагогикалық қолдау көрсету [24].

Жалпы құндылық бағдарға қоршаған орта, адамның негізгі іс-әрекеті де үлкен әсерін тигізеді. Сондықтан құндылық бағдар біріншіден, адам белсенділігіне түрткі болатын реттеушілік; екіншіден, адамның өмірлік мақсаттарының ішкі қайнар көзі қызметтерін атқарады.

Демек құндылық бағдар студенттің бүкіл өмір әрекеттерін, әлеуетін, бүкіл ішкі мотивтері мен ұмтылыстарын толығымен ашу арқылы көрінетін өмірлік талпынысы. Ол адамның тұлғалық ерекшеліктеріне ғана емес, оның әлеуметтік жағдайларда өзін-өзі көрсетуі мен өзін-өзі анықтауы кезіндегі іс-әрекетін саналы ұйымдастыруына да ерекше әсер ететін құбылыс.

Қоғам дамуының заманауи кезеңі отбасын құру және оны сақтау үшін кез келген адамның адамгершілік жауапкершілігін арттыруда. Жыл сайын көптеген неке тіркеледі, бірақ барлық отбасы өмірлік сынақтан ойдағыдай өте бермейді. Осындай жағдайлардың негізгі себептерінің бірі отбасын құруға және некеге тұруға дайындықтың болмауы, отбасылық қарым-қатынас саласынан элементарлық білімнің жеткіліксіздігі, отбасы мен некедегі әлеуметтік рөлін дұрыс түсінбеуі болып табылады.

Осыдан студент жастарды некеге тұруға дайындау әлеуметтік тәрбие үдерісінің маңызды компоненті болуы тиіс. Мұндай дайындыққа психологиялық тұрғыдан жетілгендіктен, студент жастар мұқтаж. Бұл жаста өмірлік жарының идеалды бейнесі қалыптасады, жоспар құрады, өз отбасын құрайды [25].

Жоғары оқу орнының әлеуметтік ортасы қазіргі заман жағдайында студент жастардың көзқарасы мен мінез-құлқын түзетуге үлкен әсерін тигізеді. Сондықтан некеге, отбасын құруға, отбасыадамгершілік құндылықтарын қалыптастыруға позитивті көзқарастарын қалыптастыру үшін барлық мүмкіндіктерді пайдалану қажет.

Қорыта келгенде, отбасын зерттеудің тұғырлары мен тұжырымдамаларын талдау өткен және қазіргі заман зерттелінуші студенттердің отбасы мәнін әртүрлі тұрғыдан түсінгенін және түсіндіргенін, бірақ соған қарамастан, барлығына ортақтық - отбасының: біріншіден, әлеуметтік-құнды феномен, адамзаттық тұрмыс-тіршіліктің объективті формасы ретінде; екіншіден, қоғамдық тәртіп қалыптасқан негіз ретінде; үшіншіден, отбасының тарих барысында қоғаммен бірге әрекет еткен, бірге дамыған қоғамдық дамудың өнімі ретінде мойындалуы. Нақты отбасының құндылығын оның мәдениеті анықтайды. Отбасы мәдениеті материалдық және рухани құндылықтар жиынтығынан тұрады, ол тарихи дамудың нәтижесі болып табылады.

Сондықтан әдіснамалық тұғырларды бөліп көрсету бұл саладағы өзекті мәселелерді иерархиялық ретімен белгілеуге, осы зерттеу мәселесін шешудің стратегиялық мен тактикасын айқындауға, тәжірибелік жұмыстың нәтижелерін болжамдайды.

Зерттеу нәтижелері. Жоғарыда айтылғандардың барлығын зерделей келе, «Oтбасы-адамгершілік құндылыққтарды құалыптастыру - отбасының әрбір мүшесінен өмір бойы үлкен шыдамдылықты талап ететін және өмірлік мәнді қарым-қатынас үдерісі», - деп анықтама береміз. Бұл педагогикалық жоғары оку орындары студенттерінің отбасы - адамгершілік құндылықтарын қалыптастыруда ғылыми-педагогикалық теорияларды зерттеудің нәтижесі деп қарастырамыз.

Мақаламыздың мазмұнында талданған әдіснамалық аппаратты қамтамасыз ететін әдіснамалық тұғырларды негіздей келе, аксиологиялық тұғыр - кәсібилік, өзіне сенімділік, жауапкершілік; әлеуметтік-гуманистік тұғыр - адамгершілік, ізгілік, құрмет, таным; жүйелілік-құрылымдық тұғыр білім, білік, давды біртұтас бүтіндікті құрайтын даму, дербестік; іс-әрекеттік тұғыр - шывармашылық, сенімділік, субъект-субъектілік құарым-қатынас; мәдениеттанымдық тұғыр - мәдениет, ұлттық мінез-құлық, табиват әсемдігі, өнер т.б. атрибуттарды реттейтіні анықталды.

Ендеше эксперимент алгоритміне сай қазіргі заманғы әлеуметтік-мәдени өзгерістер жағдайындағы 
студенттердің отбасы-адамгершілік құндылықтарын қалыптастыруда эксперимент жұмыстарын ұйымдастыруға мүмкіндік аламыз.

Біз педагогика-психология білім беру бағдарламасының білім алушыларымен эксперимент жұмыстарын ұйымдастырдық. Эксперименттік жұмыстар барысында студенттердің құндылықтың нақты ұстанымына қатынасын анықтауға мүмкіндік беретін М.Рокичтің «Құндылық бағдарды анықтау» әдістемесі қолданылды. Бұл әдістеменің мақсаты құндылық бағдарды анықтау болып табылады. Бұл әдістемені жүргізуге мынадай нұсқау беріледі: Сізге өз өміріңізде басшылыққа алатын құндылықтардың А (терминалды)) тізімдері таратылады. Міндетіңіз - оларды Сіз үшін маңыздылығы бойынша ретімен орналастыру. Сіз үшін мәнді болып табылатын бұл тізімдердің әрбір бөлігіне 1-ден 5-ке дейінгі балл қойыңыздар, мұнда «5» - ең жоғары балл, ал «1» өте төмен балл [26]. Анықтау экспериментіне барлығы 120 студент, оның БТ-55 студенті, ал ЭТ-65 студенті қамтылды.

Дискуссия. Нәтижелерді талдау.

Біз, анықтау экспериментіне 120 студент қатынасты, оның 55-і БТ-да, 65-і ЭТ-да сауалнамаға қатысты. Жалпы эксперимент нәтижесін пайыздық, сандық талдаулар арқылы беріп өтейік.

Сонымен нәтижені талдау студенттер терминалды құндылықтардың ішінен денсаулық, сүйікті (қызықты) жұмыс, махаббат, материалдық жағдай, адал достың болуы, бақытты отбасылық өмір алғашқы орындарға қоятыны анықталды (2-кесте).

Кесте-2. М.Рокичтің «Құндылық бағдарды анықтау» (Атізімі) әдістемесі бойынша анықтау экспериментіндегі зерттелуші топтардың терминалды құндылықтарының көрсеткіштері (\%)

\begin{tabular}{|l|l|l|l|}
\hline № & Терминалды құндылықтар тізімі & $\begin{array}{l}\text { Бақылау } \\
\text { тобы БТ(55с) }\end{array}$ & $\begin{array}{l}\text { Эксперименттік } \\
\text { топ ЭТ(65с) }\end{array}$ \\
\hline 1 & Белсенді әрекетті өмір & 3,65 & 3,77 \\
\hline 2 & Өмірлік даналық & 3,18 & 3,28 \\
\hline 3 & Денсаулық & 9,15 & 9,55 \\
\hline 4 & Сүйікті (қызықты) жұмыс & 12,14 & 12,27 \\
\hline 5 & Табиғат пен өнердің әсемділігі & 3,32 & 3,54 \\
\hline 6 & Махаббат & 8,95 & 8,98 \\
\hline 7 & Материалдық жағдай & 12,35 & 12,70 \\
\hline 8 & Адал достың болуы & 7,22 & 7,21 \\
\hline 9 & Өзге адамдардың құрметіне бөлену & 3,10 & 3,08 \\
\hline 10 & Таным & 3,87 & 3,04 \\
\hline 11 & Табысты өмір & 3,62 & 3,41 \\
\hline 12 & Даму & 3,12 & 3,13 \\
\hline 13 & Дербестік & 3,47 & 3,85 \\
\hline 14 & Бақытты отбасылық өмір & 10,42 & 10,5 \\
\hline 15 & Басқаның бақыты & 3,62 & 3,46 \\
\hline 16 & Шығармашылық & 3,34 & 3,16 \\
\hline 17 & Өзіне деген сенімділік & 3,48 & 3,14 \\
\hline 18 & $\begin{array}{l}\text { Жоғары әлеуметтік дәреже (ақша, билік, } \\
\text { мәнсап) }\end{array}$ & 2,0 & 1,93 \\
\hline
\end{tabular}

М.Рокичтің «Құндылық бағдарды анықтау» әдістемесі бойынша анықтау экспериментіндегі зерттелуші топтардың термнналды құндылықтары көрсеткіштерінің днаграммасы (2-суретте) кескінделген. 


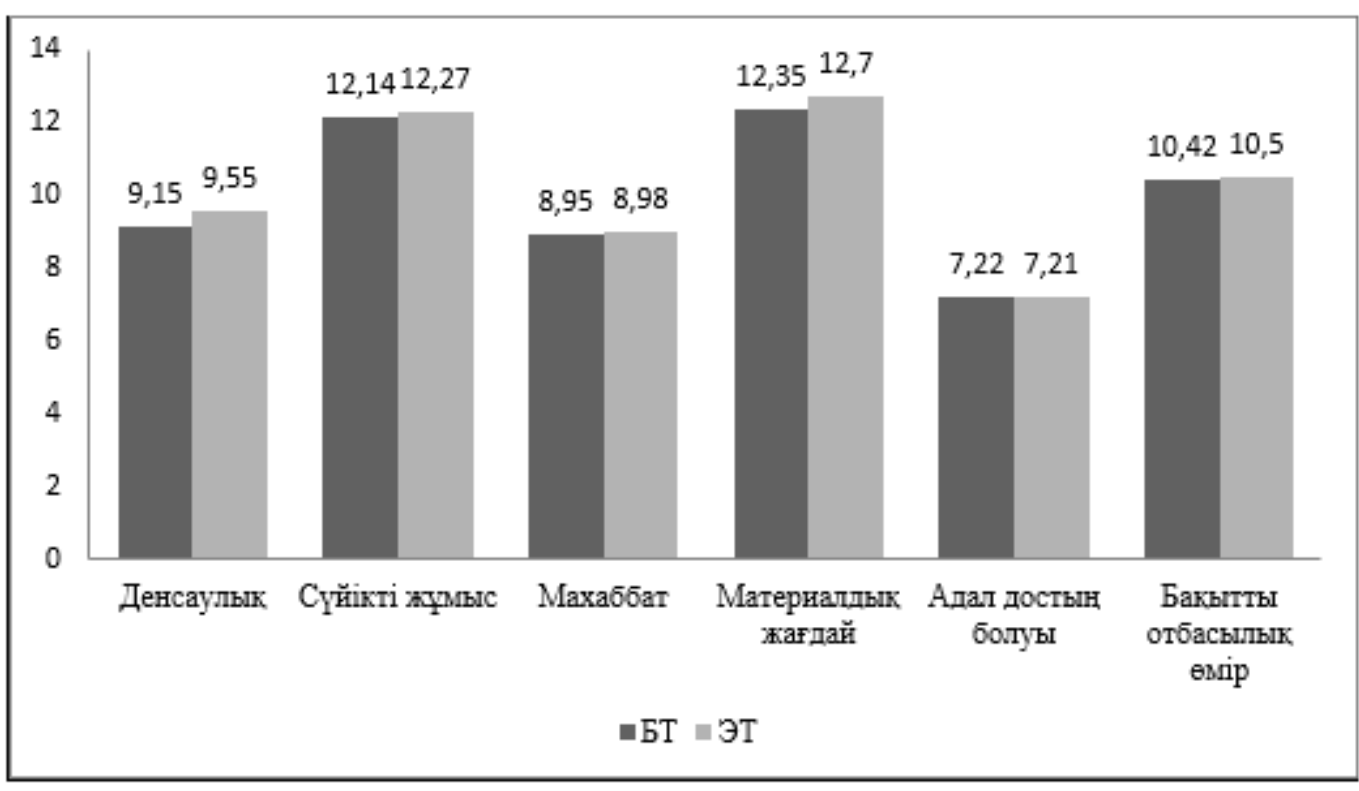

Сурет 2 - М.Рокичтін «Құндылық бағдарды анықтау» әдістемесі бойынша анықтау экспериментіндегі зерттелуші топл Область диаграммы құндылықтары көрсеткіштерінің
днаграммасы

Кесте және диаграммадан көріп отырғанымыздай, белсенді әрекетті өмір БТ-3,65 ал ЭТ-3,77; өмірлік даналық БТ-3,18, ал ЭТ-да -3,28 пайыздық көрсеткішті құрайды. Денсаулық БТ-9,15, ЭТ-да 9,55 көрсетті. Сүйікті жұмыс БТ-да12,14 ал ЭТ-да 12,27 ні құрап отыр. Табиғат пен өнердің әсемділігі БТ-да 3,32, ЭТ-да 3,54 ті анықтады. Мысалы, бақытты отбасылық өмір БТ-да 10,42 ал ЭТ-да 10,5 ті құрайды. Ал А тізімі бойынша жоғары әлеуметтік дәреже БТ-да 2,0 ал ЭТ-да 1,93 пайыздық көрсеткішті айқындайды. Бұл терминалдық құндылықтардың басым көпшілігі нақты және жеке категорияға жатады, ал студенттердің айналасындағы адамдармен өзара әрекеті мен ықпалы интеллектуалды құндылықтардан басымырақ болды.

Қорытынды. Жалпы алғанда біздің диагностикалық анықтау жұмыстары зерттеудің нәтижелерін сапалы талдау адамның өмірлік идеалын, өмірлік мақсаттарының иерархиясын, құндылықтарын, мінез-құлық нормалары туралы түсініктерін бағалауға мүмкіндік береді. Мысалы, терминалды құндылықтар ішінен бөліп көрсетіледі, нәтижелері бойынша тұлғаның құндылық бағдарының жеке жүйесінің заңдылықтары туралы түсініктерін құруға болады. Біздің осы еңбегіміздегі студенттердің отбасы-адамгершілік құндылықтарын қалыптастырудың әдіснамалық аппаратында түзілген атрибуттардың жалпы көрінісін анықтау эксперимент диагностикалық жұмыстардың нәтижесі барысында жүйеленді. Теориялық талдаулар, зерттеу әдістері, тәжірибелік жұмыстар барысы алдағы кезеңдерде өз жалғасын тауып, қалыптастырушы эксперимент жұмыстарын толықтыруға үлкен мүмкіндік берді.

Пайдаланылван ддебиеттер тізімі:

1 «Қазақстан 2020: болашаққа жол» Қазақсттан Республикасы тмемлекеттік жастар саясатының 2020 жылга дейінгі тұжырымдамасы Астана, 2019. 1 сәуір.

http://politex.kz/index.php/kz/studentterge/zhastar-sayasaty/92-2020-zh-dejingi-zhastar-sayasatyny-tzhyrymdamasy

2 https://primerminister.kz

3 Таубаева Ш.Т. Педагогика ддіснамасы. - Алматы: Қарасай баспасы, 2013. - 384 б.

4 Absatova M.A., Nishanbayeva S.Z., Nurpeisova T., Atemova K.A. Experimental Study on family formation and moral values of students International journal of intellectual disability - diagnosis and treatment 2018, VOL. 6, NO. 3, 2292-2598.

5 Пидкасистый П.И., Педагогика /аударгандар Ахметова Г.К., Таубаева Ш.Т. - Алматы: Қазак ұлтық университеті, 2006. - 336 б.

6 Бондаревская Е.В. Теория и практика личностно-ориентированного образования. - Ростов, 2000. $-352 c$.

7 Асмолов А.Г. Личность как предмет педагогического исследования. - М.: МГУ, 1984. - 312 б. 
Абай атындавы ҚазҰПУ-цц ХАБАРШЫСЫ «Педагогика вылымдары» сериясы, №3(67), 2020 ж.

8 Воложина О.И. Аксиологические основы государственной семейной политики в России // Российское общество. - 2012. - №3. - С.109-115.

9 Тұрвынбаева Б.А. Андрагогика: оку құралы. - Алматы: Алатау, 2011. - Б.62.

10 Нишанбаева С.3. Студенттердің отбасы-адамгершілік құндылықтарын қ̧алыптастыру негіздері: оку-ддістемелік құрал. - Алматы, 2018. - 76 б.

11 Пивоев В.М. Философия: Учебное пособие для гуманитарных факультетов. Часть II. Основы философских знаний. - 2-е изд. - М.: Директ-Медиа, 2013. - 435 с.

12 Каптерев П.Ф. Задачи и основы семейного воспитания // Семейное воспитание: Хрестоматия. Сост. П.А. Лебедов. - М.: Академия, 2001. - С.203-230.

13 Леонтьев А.Н. Деятельность, сознания, личность. - М.: Политиздат, 1975. - 304 c.

14 Степанов Е.Н. Личностно-ориентированный подход в работе педагога: разработка и использование / Пеод ред. Е.Н. Степанова. - М.: ТЦ Сфера, 2003. - 128 с.

15 Нургалиева Г.К. Ценностные ориентации личности: методология, теория, практика формирования. - Алматы, 1993. - 334 c.

16 Королева Ю.Г. Актуализачия иенностей семьи в жизненных планах студентов: дисс. ... канд. пед. наук. - Великий Новгород, 2008. - 200 с.

17 Сериков В.В. Личностный подход в образовании: Конщепџия и технология: Монография. Волгоград: Перемена, 1994. - 150 с.

18 Хили Р. Семейные решения и соџиальная политика: социологический аспект // Измененение положения женщины и семья. - М.: Наука, 1977. - С.107.

19 Нишанбаева С.3. ЖОО студенттерінің отбасы-адамгершілік құндылықтарын қальпттастырудың ддіснамалық тұвырлары // International Scientific Conference «Modern scientific challenges and trends». - Warsaw, 2018. - P.52-58.

20 Парсонс Т. Система современных обществ. - М.: Аспект-Пресс, 1997. - 270 с.

21 Москвичева Н.Л. Семья в системе иенностных ориентаций личности студента. дис.канд. психоло. наук. - Санкт-Петерьург, 2000. - 165 с.

22 Бердяев Н.А. О человеке, его свободе и духовности. Избранные труды / Ред. сост. Л.И. Новикова и И.Н. Сиземская. - М.: Изд-во «Флинта», 1999. - 312 с.

23 Әлққожаева Н.С. Қазіргі кездегі білім беру парадигмалары контексінде тұлzаның рухани дүниесін қалыптастырудың вылыли-педагогикалық негіздері: Монография. - Алматы: Қазақ университеті, 2013. - 156 б.

24 Мудрик А.В. Вызовы глобального кризиса и новые проблемы сочиализации подростков // Библиотека и чтение в структуре современного образования: материаль межрегиональной научной конференции. - М.: Наука, 2009. - C.128-133.

25 Атемова Қ.Т. Қазақ отбасы тәрбиесінің даму тарихы. Монография. - Алматы: «Қазақ университеті, 2007. - 351 б.

26 Rokeach M. The Nature of Human Values. - N.Y.: Free Press.1973. - 438 p. https://academic.oup.com

Reference:

1. The concept of the state youth policy of the Republic of Kazakhstan until 2020 "Kazakhstan 2020: the way to the future" Astana, 2019. April 1.http://politex.kz/index.php/kz/studentterge/zhastar-sayasaty/922020-zh-dejingi-zhastar-sayasatyny-t-zhyrymdamasy

2. https://primerminister.kz

3. Taubaeva Sh.T. Methodology of pedagogy. - Almaty: Karasai Publishing House, 2013. - 384 p.

4. Absatova M.A., Nishanbayeva S.Z., Nurpeisova T., AtemovaK.A. Experimental Study on family formation and moral values of students International journal of intellectual disability - diagnosis and treatment 2018, VOL. 6, NO. 3, 2292-2598.

5. Pidkasisty PI, Pedagogy / translated by Akhmetova GK, Taubaeva Sh.T. - Almaty: Kazakh National University, 2006. - 336 p.

6. Bondarevskaya E.V. Theory and practice of student-centered education. - Rostov, 2000 --- 352 p.

7. Asmolov A.G. Personality as a subject of pedagogical research. - Moscow: Moscow State University, 1984 .-- $312 b$.

8. Volozhina O.I. Axiological foundations of state family policy in Russia // Russian Society. - 2012. - No. 3. - S.109-115. 
9. Turgunbayeva BA Andragogy: a textbook. - Almaty: Alatau, 2011. - P.62.

10. Nishanbaeva SZ Basics of formation of family and moral values of students: textbook. - Almaty, 2018. $-76 p$.

11. Pivoev V.M. Philosophy: Textbook for Humanities Faculties. Part II. Fundamentals of philosophical knowledge. - 2nd ed. - M .: Direct-Media, 2013 .-- 435 p.

12. Kapterev P.F. Tasks and foundations of family education // Family education: Reader. Compiled by P.A. Lebedov. - M .: Academy, 2001 --- S.203-230.

13. Leontiev A.N. Activity, consciousness, personality. - M .: Politizdat, 1975 .-- 304 p.

14. Stepanov E.N. Personality-oriented approach in the work of a teacher: development and use / Ed. E.N. Stepanov. - M .: TC Sphere, 2003 .-- 128 p.

15. Nurgalieva G.K. Personal value orientations: methodology, theory, practice of formation. - Almaty, $1993 .--334 p$.

16. Koroleva Yu.G. Actualization of family values in the life plans of students: diss. ... Cand. ped. sciences. - Veliky Novgorod, 2008 .-- 200 p.

17. Serikov V.V. Personal approach in education: Concept and technology: Monograph. - Volgograd: Change, 1994. - $150 \mathrm{p}$.

18. Healy R. Family decisions and social policy: the sociological aspect // Changing the position of women and the family. - M .: Nauka, 1977 .-- P.107.

19. Nishanbaeva SZ Methodological bases of formation of family and moral values of university students // International Scientific Conference "Modern scientific challenges and trends». - Warsaw, 2018. - P.5258.

20 Parsons T. System of modern societies. - M .: Aspect-Press, $1997 .--270$ p.

21. Moskvicheva N.L Family in the system of value orientations of the student's personality. dissertation psychologist. science. - Saint-Petersburg, 2000. - 165 p.

22. Berdyaev N.A About man, his freedom and spirituality. Selected works / Ed. cocm. L.I. Novikova and IN Sizemskaya. - M .: Flinta Publishing House, 1999. - 312 p.

23. Alkozhaeva N.C. Scientific and pedagogical basis for the formation of the spiritual world of the individual in the context of modern educational paradigms: Monograph. - Almaty: Kazakh University, 2013. $-156 \mathrm{p}$.

24. Mudrik A.V Challenges of the global crisis and new problems of socialization of adolescents // Library and reading in the structure of modern education: materials of an interregional scientific conference. - M .: Nauka, 2009 .-- S. 128-133.

25. Atemova K.T History of the development of Kazakh family education. Monograph. - Almaty: "Kazakh University, 2007. - $351 \mathrm{p}$.

26. Rokeach M. The Nature of Human Values. -N.Y.: Free Press.1973. - 438 p.https://academic.oup.com

МРНТИ: 14.35 .07

https://doi.org/10.51889/2020-3.1728-5496.07

Ш.С. Демисенова ${ }^{l}$

${ }^{I}$ А.Байтұрсынов атындавы Қостанай аймақтық университет

\section{ӘЛЕУМЕТТІК-ПЕДАГОГИКАЛЫК КЕНЕС БЕРУДІ ҰЙЫМДАСТЫРУ \\ ТӘЖІРИБЕСІ ТҰЛҒА ТОЛЕРАНТТЫҒЫ МЕН ЭТНОМӘДЕНИ КҰЗЫРЕТТІЛІГІН ҚАЛЫПТАСТЫРУ ТЕХНОЛОГИЯСЫ РЕТІНДЕ}

Aң̧датпа

Мақалада этникалық қатынастар саласында әлеуметтік-педагогикалық кеңес беру рөлі, оның ерекшеліктері және кеңес берушіге қойылатын талаптармен байланысты мәселелер қарастырылады. Ұлтаралық қатынастар мәселелері бойынша кеңес беру тарихы, кеңес берудің этикалық және эмикалық тәсілдемелері қысқаша сипатталды.

Этникалық қатынастар мәселелері бойынша кеңес беру кезіндегі кеңестік үрдіс ерекшеліктері 